\title{
Perception of Gastrointestinal Endoscopy Personnel on Society Recommendations on Personal Protective Equipment, Case Selection, and Scope Cleaning During Covid-19 Pandemic: An International Survey Study
}

\author{
Parit Mekaroonkamol', Kasenee Tiankanon', Rapat Pittayanon ${ }^{1,2}$, Wiriyaporn Ridtitid ${ }^{1,2}$, Fariha Shams ${ }^{3}$, Ghias Un Nabi Tayyab ${ }^{4}$, \\ Julia Massaad ${ }^{5}$, Saurabh Chawla ${ }^{5}$, Stanley Khoo ${ }^{6}$, Siriboon Attasaranya ${ }^{1,7}$, Nonthalee Pausawasdi ${ }^{8}$, Qiang Cai ${ }^{5}$, Thawee \\ Ratanachu-ek ${ }^{7}$, Pradermchai Kongkham ${ }^{1,2}$, and Rungsun Rerknimitr ${ }^{1,2}$ \\ ${ }^{1}$ Division of Gastroenterology, Department of Medicine, Faculty of Medicine, Chulalongkorn University and King Chulalongkorn \\ Memorial Hospital, Thai Red Cross, Bangkok, ${ }^{2}$ Center of Excellence for Innovation and Endoscopy in Gastrointestinal Oncology, \\ Chulalongkorn University, Bangkok, Thailand, ${ }^{3}$ Division of Radiology, Jinnah Hospital, Lahore, ${ }^{4}$ Division of Gastroenterology, Lahore \\ General Hospital, Lahore, Pakistan ${ }^{5}$ Division of Digestive Diseases, Department of Internal Medicine, Emory University, Atlanta, GA, \\ USA, ${ }^{6}$ Gastroenterology and Hepatology Unit, Department of Medicine, Faculty of Medicine, University of Malaya, Kuala Lumpur, \\ Malaysia, ${ }^{7}$ Department of Surgery, Rajavithi Hospital, Bangkok, Thailand, ${ }^{8}$ Division of Gastroenterology, Department of Medicine, Siriraj \\ Hospital, Mahidol University, Bangkok, Thailand
}

Background/Aims: The Thai Association for Gastrointestinal Endoscopy published recommendations on safe endoscopy during the coronavirus disease 2019 (COVID-19) pandemic. This study aimed to assess the practicality and applicability of the recommendations and the perceptions of endoscopy personnel on them.

Methods: A validated questionnaire was sent to 1290 endoscopy personnel globally. Of these, the data of all 330 responders (25.6\%) from 15 countries, related to the current recommendations on proper personal protective equipment (PPE), case selection, scope cleaning, and safety perception, were analyzed. Ordinal logistic regression was used to determine the relationships between the variables.

Results: Despite an overwhelming agreement with the recommendations on PPE (94.5\%) and case selection (95.5\%), their practicality and applicability on PPE recommendations and case selection were significantly lower $(p=0.001, p=0.047, p<0.001$, and $p=0.032$, respectively). Factors that were associated with lower sense of safety in endoscopy units were younger age $(p=0.004)$, less working experience $(p=0.008)$, in-training status $(p=0.04)$, and higher national prevalence of COVID-19 $(p=0.003)$. High prevalent countries also had more difficulty implementing the guidelines $(p<0.001)$ and they considered the PPE recommendations less practical and showed lower agreement with them ( $p<0.001$ and $p=0.008$, respectively). A higher number of in-hospital COVID-19 patients was associated with less agreement with PPE recommendations $(p=0.039)$.

Conclusions: Using appropriate PPE and case selection in endoscopic practice during a pandemic remains a challenge. Resource availability and local prevalence are critical factors influencing the adoption of the current guidelines. Clin Endosc 2022;55:215-225

Key Words: COVID-19; Endoscopy; Guidelines; Recommendations; Survey

Received: January 18, 2021 Revised: February 26, 2021

Accepted: February 27, 2021

Correspondence: Rungsun Rerknimitr

Division of Gastroenterology, Department of Medicine, Chulalongkorn University, 1873 Rama IV Rd., Bangkok 10330, Thailand

Tel: +66-2-256-4265, Fax: +66-2-652-4129, E-mail: ercp@live.com

ORCID: https://orcid.org/0000-0001-6866-6886

(c) This is an Open Access article distributed under the terms of the Creative Commons Attribution Non-Commercial License (http://creativecommons.org/ licenses/by-nc/3.0) which permits unrestricted non-commercial use, distribution, and reproduction in any medium, provided the original work is properly cited.

\section{INTRODUCTION}

The rapidly evolving coronavirus disease 2019 (COVID-19) pandemic caused by SARS-COV-2 continues to pose unprecedented challenges to global medical communities and it has changed the way medicine is practiced globally. Due to its alarmingly high transmission rate, even among asymptomatic patients, ${ }^{1,2}$ it is essential for healthcare personnel to be extremely cautious during all patient interactions, especially 
when aerosol-generating procedures (AGPs) are performed.

COVID-19 can manifest with various gastrointestinal symptoms; therefore, gastroenterologists are particularly at risk of inadvertent exposure. ${ }^{3-5}$ All endoscopic procedures should be considered AGPs, and the relevant precautions should be enforced. ${ }^{6-11}$ Gastrointestinal societies have published recommendations on personal protective equipment (PPE) and case selection for safe endoscopy during the COVID-19 pandemic. $^{7,8,12-15}$

Like other medical societies, the Thai Association for Gastrointestinal Endoscopy (TAGE) strives to provide a safe platform for its members-endoscopists, endoscopy nurses, technical assistants, and all other endoscopy personnel-to deliver safe and effective patient care. TAGE recently published its recommendations on endoscopic practice during the COVID-19 pandemic, focusing on the required PPE, case selection, and scope cleaning process. ${ }^{13}$

However, there are discrepancies in resource supply and institutional capability, which questions whether such recommendations can be implemented in real-world practice. This study aimed to evaluate the practicality of the gastrointestinal society recommendations, as perceived by endoscopy unit staff, using a questionnaire-based survey. The secondary aim was to assess the perceptions of safety related to endoscopic procedures performed during the COVID-19 pandemic among endoscopy personnel.

\section{METHODS}

An international survey was conducted. A web-based online questionnaire consisting of 24 questions was developed to evaluate the perceptions of endoscopy personnel on the TAGE recommendations during the COVID-19 pandemic. The content of the survey was validated by a panel of experts (Supplementary Material 1). The population of interest included endoscopists (gastroenterologists and surgeons), endoscopy nurses, and technical assistants. All participants had to sign a written consent electronically for the survey. The study was approved by the Institutional Review Board of Chulalongkorn University.

The survey was sent to all board-certified physician endoscopists, registered endoscopy nurses, and fellows-in-training according to the TAGE National Membership Office database. In addition, the TAGE recommendations were published on social media platforms (Fig. 1). The survey was sent to Facebook $^{\circledR}$ (Facebook, Inc., Menlo Park, CA, USA) users who shared the recommendations and were identified as endoscopy staff according to their public profile. Relevant credentials and demographic data such as job position, level of training, level of care provided at the employing institution, working experience, and volume of endoscopy cases were included in the questionnaire and systematically analyzed.

TAGE recommended (a) PPEs based on patient risk stratification and (b) prioritizing endoscopic procedures as emergent, urgent, and elective for case selection, which were consistent with recommendations from the Asian-Pacific Society of Digestive Endoscopy, Society of American Gastrointestinal and Endoscopic Surgeons, and Center of Disease Control on COVID-19 statements (Fig. 1). ${ }^{7,16}$ To minimize inadvertent droplets or aerosol splash from channel irrigation, TAGE recommended three additional steps during the pre-cleaning process, as shown in Fig. 1. ${ }^{17}$

Personal demographics and work-related data from the survey respondents were collected. All responses were anonymous. The questionnaire focused on three main aspects of the recommendations: (1) PPE during endoscopy, (2) case selection to be performed during the pandemic, and (3) scope cleaning process (Supplementary Material 1). The level of agreement, perceived practicality, and ability to implement each recommendation were assessed using a Likert scale ranging from 1 to 5 .

The web link of the questionnaire was distributed via email, Line ${ }^{\circledR}$ (Line Corporation, Tokyo, Japan), and Facebook ${ }^{\circledR}$ messenger applications. Two reminders were sent to all recipients at weekly intervals to increase the response rate.

Respondents would be considered from a low prevalent country if there were only "sporadic cases" according to the WHO categorization or a "cluster of cases" that did not exceed 10,000 accumulated cases per million population. High prevalence countries were defined as those with "community spread" or $>10,000$ accumulated cases per million population. $^{18}$

Univariate and bivariate analyses were also performed. Descriptive statistics were used to present continuous, ordinal, and categorical data. Mann-Whitney U and Kruskal Wallis tests were used for Likert-scale ordinal data, while chi-squared and Fisher's exact tests were used for categorical data. Ordinal logistic regression analysis was performed to identify the relationships among the variables. If there was a statistically significant difference between the analyzed groups, a posthoc analysis was performed using the Mann-Whitney U test. All statistical analyses were performed using SPSS Statistics for Windows, Version 22.0 (IBM Corp., Armonk, NY, USA).

\section{RESULTS}

The survey was distributed to all 339 TAGE members, 488 members of the Endoscopy Nurse Society of Thailand (ENST), 


\section{Recommended PPE for Endoscopy}
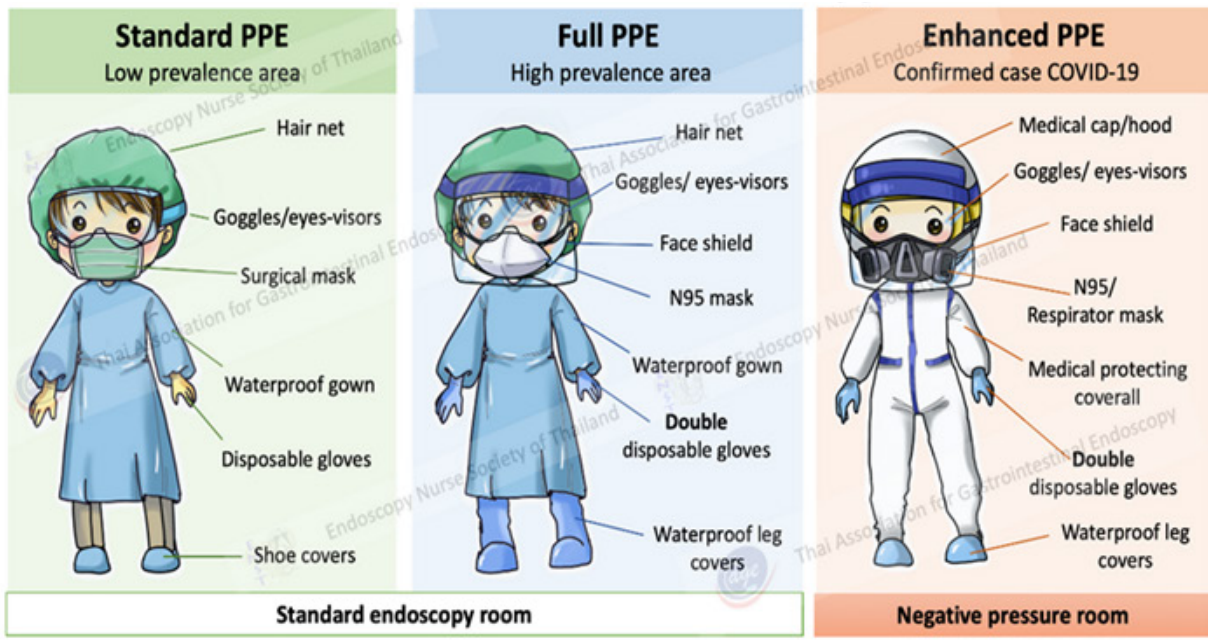

\section{Classification of endoscopic procedures during COVID-19 outbreak}

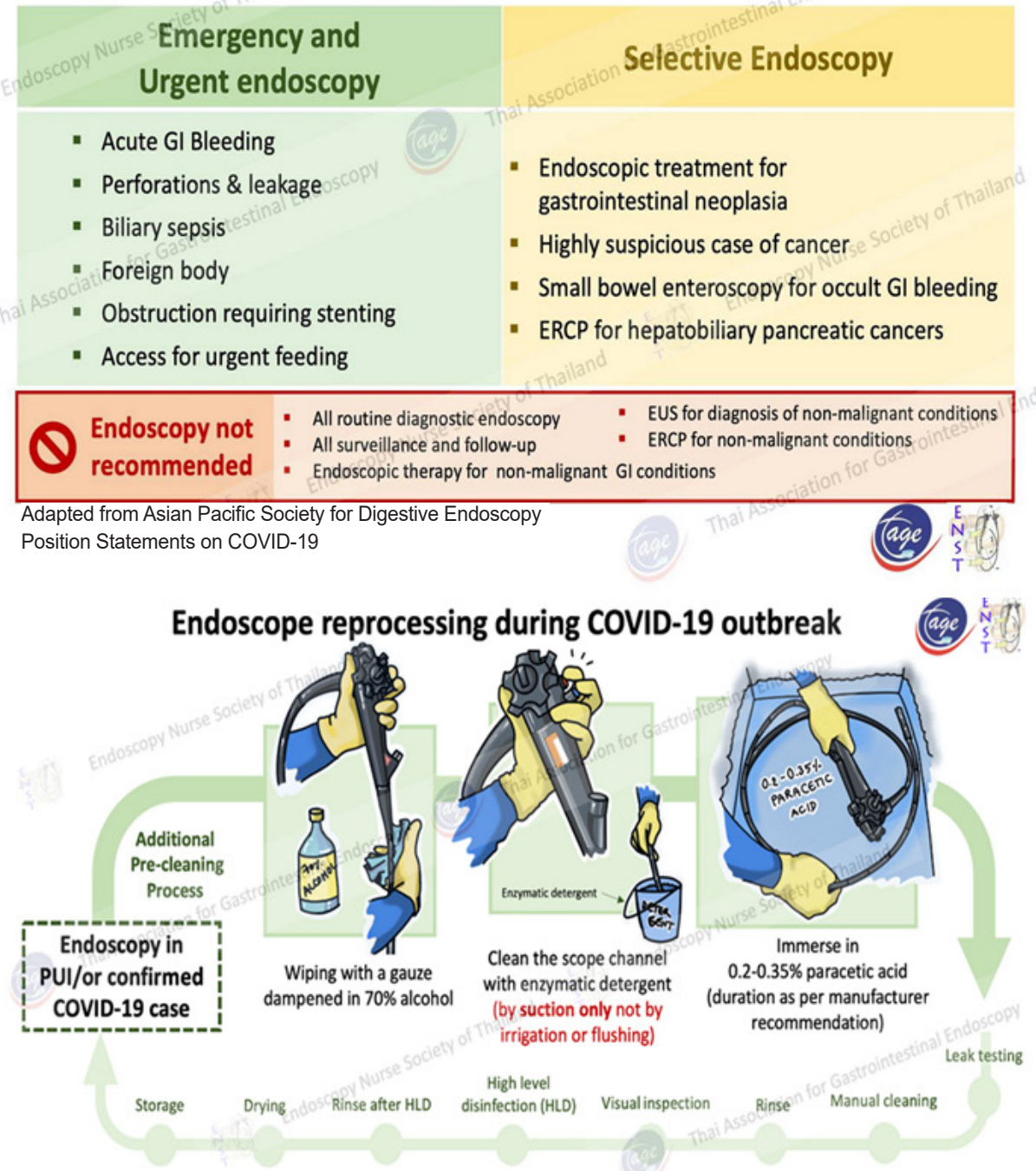

Fig. 1. The Thai Association for Gastrointestinal Endoscopy recommendations on the use of personal protective equipment, procedural classification, and scope reprocessing. PUI, patient under investigation. 
and 71 gastroenterology fellows-in-training in Thailand. A total of 927 Facebook $^{\circledR}$ users who shared published TAGE recommendations were screened. The survey was sent to 392 users who were found to be healthcare personnel in endoscopy units outside Thailand.

Of the 1290 surveys sent, 330 endoscopic personnel from 15 countries responded, accounting for a response rate of $25.6 \%$. Using 1290 as the targeted population frame with a $95 \%$ confidence interval for Cochrane's sample size formula, the corresponding correction formula yielded a $4.66 \%$ margin of error. ${ }^{19}$ The demographic data of respondents are described in Table 1.

When asked about PPE recommendations for endoscopy (Fig. 1), 94.5\% (312/330) agreed with the TAGE recommendations. In contrast with an overwhelming agreement, the practicality and applicability of the recommendations were lower $\left(\chi^{2}=40.2 ; p=0.001\right.$ and $\chi^{2}=25.8 ; p=0.047$, respectively). Only $59.4 \%$ of the respondents believed that their endoscopy units were capable of adopting the TAGE recommendations, and $15.1 \%$ reported encountering some degree of difficulty in implementing them (Fig. 2). Ordinal regression analysis showed that a higher number of COVID-19 patients being treated in the hospital was associated with a higher agreement with the PPE recommendations (Wald $\chi^{2}(1)=5.81 ; p=0.016$ ). PPE shortage and lack of administrative support were ranked as the top two main obstacles to implementing the recommendations (52\% and $31 \%$, respectively). To overcome the PPE shortage problem, most endoscopic personnel found the "doit-yourself" PPE and reusing the equipment to be the most beneficial (36.7\% and 23.9\%).

Regarding the case selection, 95.5\% $(n=315)$ agreed with the TAGE recommendations; however, only $70.9 \%$ and $67.3 \%$

Table 1. Demographic and Institutional Data of All Respondents

\begin{tabular}{lc}
\hline & $\begin{array}{c}\text { Number of respondents } \\
(\boldsymbol{n}=330)\end{array}$ \\
\hline Age (years) & $3(0.9)$ \\
Under 25 & $93(28.2)$ \\
$25-34$ & $156(47.3)$ \\
$35-44$ & $57(17.3)$ \\
$45-54$ & $21(6.4)$ \\
Over 55 & \\
Gender & $202(61.2)$ \\
Male & $128(38.8)$ \\
Female & \\
Role & $278(84.2)$ \\
Endoscopist & $44(13.3)$ \\
Endoscopy nurse & $8(2.5)$ \\
Technical assistant & \\
Work experience & $32(9.7)$ \\
Fellow-in-training & $109(33.0)$ \\
0-5 years & $92(27.9)$ \\
5-10 years & $46(13.9)$ \\
10-15 years & $51(15.5)$ \\
More than 15 years & \\
Institutional level of care & $10(3.0)$ \\
Primary care & $47(14.2)$ \\
Secondary care & $273(82.7)$ \\
Tertiary care & \\
Institutional funding & $58(17.6)$ \\
Private practice & $272(82.4)$ \\
Governmental hospital & \\
\hline & \\
\hline & \\
\hline
\end{tabular}

\begin{tabular}{|c|c|}
\hline & $\begin{array}{l}\text { Number of respondents } \\
\qquad(n=330)\end{array}$ \\
\hline \multicolumn{2}{|c|}{$\begin{array}{l}\text { Case volume prior to COVID- } 19 \\
\text { pandemic per day }\end{array}$} \\
\hline $0-10$ & $71(21.5)$ \\
\hline $11-20$ & $105(31.8)$ \\
\hline $21-30$ & $59(17.9)$ \\
\hline $31-40$ & $28(8.5)$ \\
\hline $41-50$ & $25(7.6)$ \\
\hline More than 50 & $42(12.7)$ \\
\hline \multicolumn{2}{|c|}{$\begin{array}{l}\text { Number of COVID- } 19 \text { cases being } \\
\text { treated in the hospital }\end{array}$} \\
\hline None & $65(19.7)$ \\
\hline $1-10$ & $107(32.4)$ \\
\hline $11-20$ & $42(12.7)$ \\
\hline $21-30$ & $26(7.9)$ \\
\hline More than 30 & $90(27.3)$ \\
\hline \multicolumn{2}{|l|}{ Region of practice } \\
\hline Southeast Asia & $180(54.5)$ \\
\hline South Asia & $97(29.4)$ \\
\hline North America & $38(11.5)$ \\
\hline Europe & $9(2.7)$ \\
\hline West Asia & $5(1.5)$ \\
\hline East Asia & $1(0.3)$ \\
\hline \multicolumn{2}{|c|}{ National COVID-19 prevalence } \\
\hline High prevalence ${ }^{a)}$ & $150(45.5)$ \\
\hline Low prevalence ${ }^{\mathrm{b})}$ & $180(54.5)$ \\
\hline
\end{tabular}

Data are presented as number (\%).

COVID-19; coronavirus disease 2019.

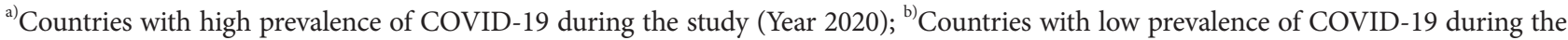
study (Year 2020), High prevalence countries were defined as those with "community spread" or $>10,000$ accumulated cases per million population. 

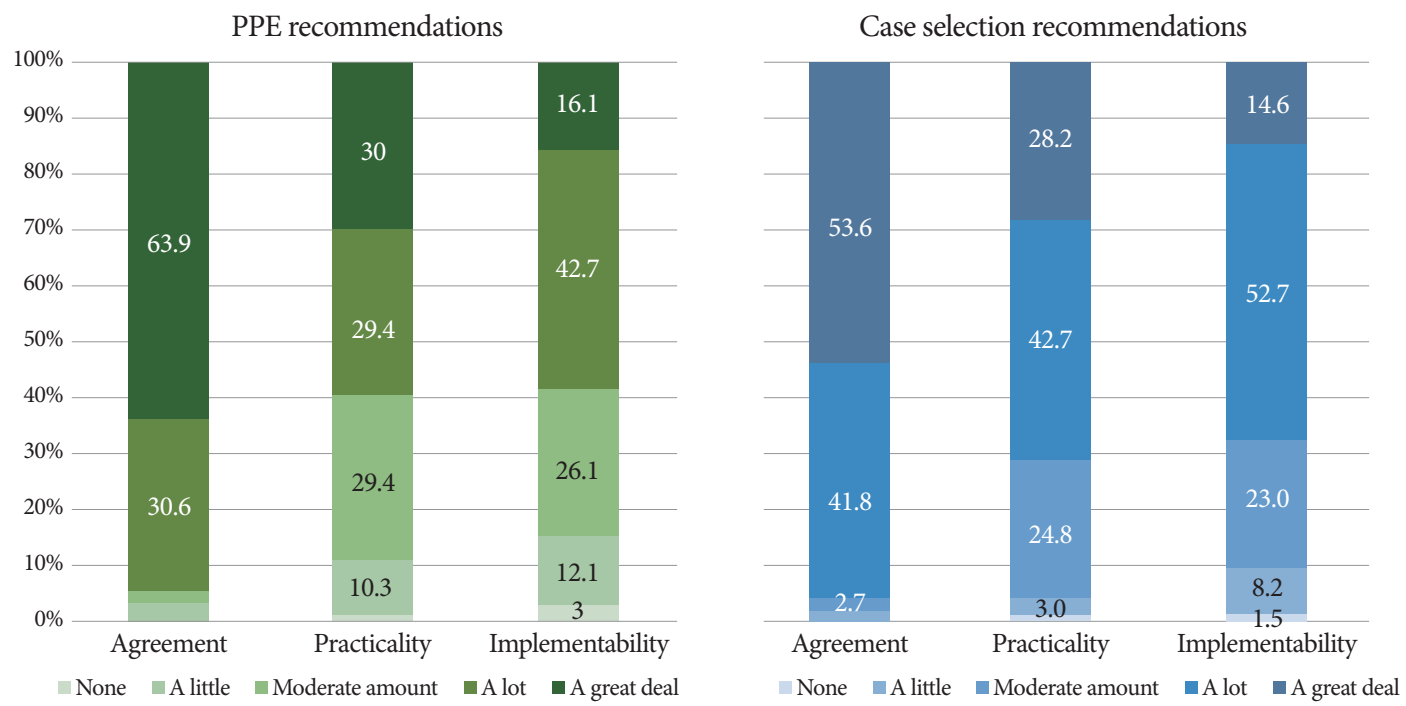

Fig. 2. Responses on the agreement with and the practicality and applicability of personal protective equipment (PPE) and case selection recommendations.

of the respondents stated that the recommendations were practical and the implementation was easy (Fig. 2) $\left(\chi^{2}=115.3\right.$; $p<0.001$ and $\chi^{2}=22.6 ; p=0.032$, respectively). Less than half (45.2\%) of the respondents reported not performing elective endoscopy during the study period. The top two reasons for non-compliance were "physician preference" and inability to reschedule".

Less than half of the respondents (46.1\%) felt "moderately safe" working in an endoscopy unit during the COVID-19 pandemic period whereas $21.5 \%$ felt a "little safe" or "not safe at all" or unsafe. The main reason for "unsafe" working conditions (80\%) was inadequate PPE provided to the endoscopy personnel.

The sense of safety of the respondents in the endoscopy unit significantly differed during the pandemic with age $\left(\chi^{2}=15.3\right.$; $p=0.004)$ and the level of experience of the endoscopy personnel $\left(\chi^{2}=17.6 ; p=0.001\right)$ (Fig. 3). After adjusting for age, multivariate ordinal regression analysis showed that greater experience was associated with better perceptions of safety (Wald $\chi^{2}(1)=13.7 ; p=0.008$ ). In the subgroup analysis of trainee responses $(n=32)$, there was no statistically significant difference in agreement, perceived practicality, or applicability of the recommendations. However, the trainees reported feeling less safe, compared with the attending physicians $(n=246)$ $(U=3,778 ; p=0.04)$, as shown in Figure 3 .

Looking at the various professional roles of the respondents, there were no statistically significant differences between the responses of the endoscopists $(n=278)$ and the endoscopy nurses $(n=44)$ related to their agreement with and the perceived practicality of the recommendations on PPE and case selection $(U=5,226 ; p=0.065$ and $U=5,998 ; p=0.83$ and $U=5,599 ; p=0.305$ and $U=5,911 ; p=0.70$, respectively). Physician endoscopists had more difficulty implementing PPE recommendations than endoscopy nurses (17\% vs. $4.6 \%$, $U=4,732 ; p=0.011)$. There was no statistically significant difference in safety perception by the physicians and endoscopy nurses $(U=4,026 ; p=0.43)$. When asked about scope cleaning protocols during the COVID-19 pandemic, the endoscopists were more likely to respond as "I do not know" than the endoscopy nurses $(U=4,276 ; p=0.001)$.

Although there were no differences in the agreement with and perceived practicality and applicability of the recommendations among the different levels of hospitals, respondents from private hospitals were more likely to perceive the recommendations for case selection to be less practical than those from governmental hospitals $(U=6,478 ; p=0.015)$. After adjusting for hospital size, ordinal regression analysis showed that the odds of respondents in private practices considering recommendations on case selection to be non-practical was 7.4 (95\% confidence interval, 2.8-4.9) times that of those from non-private practices (Wald $\chi^{2}(1)=6.17 ; p=0.013$ ), as shown in Fig. 4. The number of endoscopic procedures performed in COVID-19 patients was associated with the agreement with the case selection recommendations $\left(\chi^{2}=15.1 ; p=0.002\right)$.

Respondents from countries with a high prevalence of COVID-19 $(n=150)$ had significantly less agreement with the PPE recommendations $(U=11,570 ; p=0.008)$ and were less likely to perceive the recommendations to be practical or easily applicable, compared to low prevalent countries $(n=180)$ ( $U=10,444 ; p<0.001$ and $U=8,585, p<0.001$, respectively). Similarly, it was also more difficult to implement the recommendations on case selection and scope reprocessing in highly 
Work experience

Age group

Training status
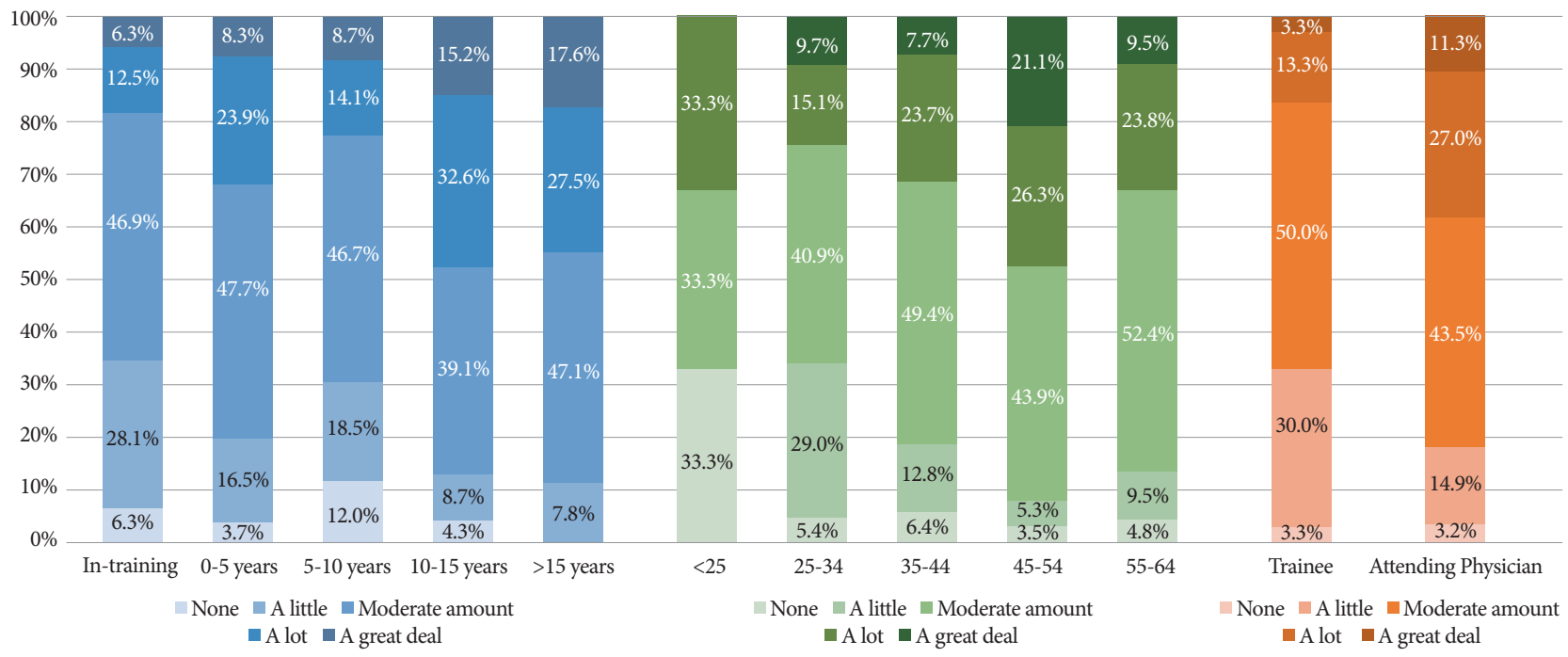

Fig. 3. Safety perception of all respondents stratified by age group, work experience, and training status.

Practicality of case selection recommendation

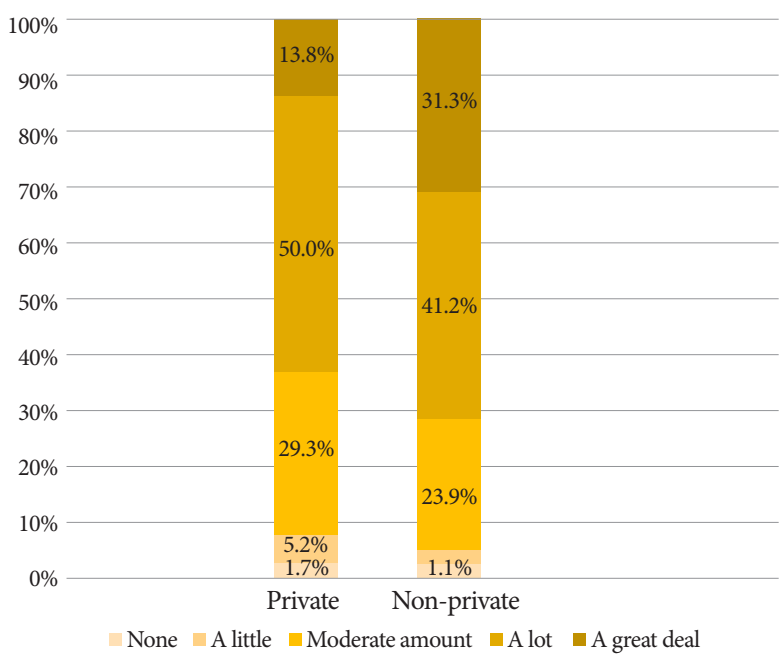

Fig. 4. Perceptions of the practicality of the recommendations on case selection by personnel in private and non-private practices.

prevalent countries $(U=9,992 ; p<0.001$ and $U=10,320$, $p<0.001$, respectively). They also felt less safe working in endoscopy units $(U=11,062 ; p=0.003)$. The associations between each parameter and the agreement with and the practicality and applicability of the recommendations are summarized in Tables 2 and 3.

\section{DISCUSSION}

As COVID-19 continues to ravage the world, endoscopy units are now adapting to the "new normal" of medical practice. Our study has demonstrated that although the recommendations of gastrointestinal societies are generally accepted, their practicality and applicability are still questioned, especially in resource-limited and/or highly prevalent areas. Coverall suit, N95 masks, and leg covers were reported as the most deficient equipment, with $37 \%$ of the respondents stating that do-it-yourself equipment and reusing the mask were the most helpful in overcoming the PPE shortage problem. ${ }^{20-24}$ At the time of this study, there has been no study validating the efficacy of one reuse method over another. Studies investigating the most cost-effective methods for reusing such equipment are needed for resource-limited medical communities.

Even though the majority of the respondents reported being able to implement the recommendations, almost half (46\%) responded neutrally to a question on safety while working in an endoscopy unit. The sense of safety did not differ with gender, professional role, institutional level, number of COVID-19 cases in the hospital, or case load of endoscopic procedures for COVID-19 patients; it differed with age, working experience, training status, and the prevalence of COVID-19 in the country. Despite the higher mortality risk associated with COVID-19 infections, ${ }^{25}$ respondents in the older age groups still felt safer working during the pandemic. These results demonstrate that the imperturbability of seasoned endosco- 
Table 2. Association between Demographic Parameters and Agreement, Practicality, and Applicability of the Recommendations on Proper Personal Protective Equipment for Endoscopy

\begin{tabular}{|c|c|c|c|}
\hline & \multicolumn{3}{|c|}{ PPE recommendation } \\
\hline & $\begin{array}{c}\text { Agreement } \\
\text { (“Strongly agree” and “Agree”) }\end{array}$ & $\begin{array}{c}\text { Practicality } \\
\text { (“A great deal” and “A lot”) }\end{array}$ & $\begin{array}{c}\text { Applicability } \\
\text { ("Very easy" and "Easy") }\end{array}$ \\
\hline Age & $p=0.792$ & $p=0.609$ & $p=0.493$ \\
\hline Under 25 & $100.0 \%$ & $33.3 \%$ & $66.7 \%$ \\
\hline $25-34$ & $92.5 \%$ & $58.1 \%$ & $54.8 \%$ \\
\hline $35-44$ & $94.9 \%$ & $60.3 \%$ & $61.5 \%$ \\
\hline $45-54$ & $96.5 \%$ & $57.9 \%$ & $57.9 \%$ \\
\hline Over 55 & $95.2 \%$ & $66.7 \%$ & $57.1 \%$ \\
\hline Gender & $p=0.302$ & $p=0.434$ & $p=0.033^{*}$ \\
\hline Male & $95.0 \%$ & $57.4 \%$ & $55.0 \%$ \\
\hline Female & $94.5 \%$ & $62.5 \%$ & $64.9 \%$ \\
\hline Work experience (years) & $p=0.523$ & $p=0.140$ & $p=0.205$ \\
\hline $0-5$ & $95.4 \%$ & $64.2 \%$ & $64.2 \%$ \\
\hline $6-10$ & $96.7 \%$ & $50.0 \%$ & $52.2 \%$ \\
\hline $11-15$ & $91.3 \%$ & $63.0 \%$ & $58.7 \%$ \\
\hline$>15$ & $96.1 \%$ & $64.7 \%$ & $60.8 \%$ \\
\hline Professional role & $p=0.065$ & $p=0.830$ & $p=0.011^{*}$ \\
\hline Physician & $94.2 \%$ & $59.4 \%$ & $56.5 \%$ \\
\hline Nurses & $95.5 \%$ & $59.1 \%$ & $70.5 \%$ \\
\hline Institutional level & $p=0.722$ & $p=0.089$ & $p=0.295$ \\
\hline Primary care & $100 \%$ & $60 \%$ & $70.0 \%$ \\
\hline Secondary care & $100 \%$ & $70.2 \%$ & $70.2 \%$ \\
\hline Tertiary care & $93.4 \%$ & $57.5 \%$ & $56.4 \%$ \\
\hline Private practice status & $p=0.888$ & $p=0.866$ & $p=0.708$ \\
\hline Private practice & $93.1 \%$ & $60.4 \%$ & $55.2 \%$ \\
\hline Governmental hospital & $94.9 \%$ & $59.2 \%$ & $59.5 \%$ \\
\hline $\begin{array}{l}\text { Number of COVID cases in the } \\
\text { hospital (cases/day) }\end{array}$ & $p=0.039^{*}$ & $p=0.055$ & $p=0.585$ \\
\hline 0 & $95.4 \%$ & $60.0 \%$ & $66.2 \%$ \\
\hline $1-10$ & $98.1 \%$ & $51.4 \%$ & $57.0 \%$ \\
\hline $11-20$ & $95.2 \%$ & $54.8 \%$ & $54.8 \%$ \\
\hline $21-30$ & $92.3 \%$ & $65.4 \%$ & $53.8 \%$ \\
\hline$>30$ & $90.0 \%$ & $68.9 \%$ & $58.9 \%$ \\
\hline $\begin{array}{l}\text { Endoscopic volume on } \\
\text { COVID-19 cases (cases/month) }\end{array}$ & $p=0.225$ & $p=0.843$ & $p=0.164$ \\
\hline 0 & $100.0 \%$ & $83.3 \%$ & $100.0 \%$ \\
\hline $1-10$ & $94.9 \%$ & $59.1 \%$ & $59.9 \%$ \\
\hline $11-20$ & $93.8 \%$ & $56.3 \%$ & $56.3 \%$ \\
\hline $21-30$ & $80.0 \%$ & $60.0 \%$ & $30.0 \%$ \\
\hline$>30$ & $100.0 \%$ & $69.2 \%$ & $53.8 \%$ \\
\hline National COVID-19 prevalence & $p=0.008^{*}$ & $p<0.001^{\star}$ & $p<0.001^{\star}$ \\
\hline Low prevalent & $96.7 \%$ & $68.3 \%$ & $72.8 \%$ \\
\hline High prevalent & $92 \%$ & $48.7 \%$ & $42.0 \%$ \\
\hline Trainee status & $p=0.919$ & $p=0.841$ & $p=0.518$ \\
\hline In-training & $86.6 \%$ & $53.4 \%$ & $53.3 \%$ \\
\hline Attending physician & $95.2 \%$ & $60.0 \%$ & $56.8 \%$ \\
\hline
\end{tabular}

COVID-19, coronavirus disease 2019; PPE, personal protective equipment.

*Statistically significant. 
Table 3. Association Between Demographic Parameters and Agreement, Practicality, and Applicability of the Recommendations on Endoscopy Case Selection during COVID-19 Pandemic

\begin{tabular}{|c|c|c|c|}
\hline & \multicolumn{3}{|c|}{ Case Selection recommendations } \\
\hline & $\begin{array}{c}\text { Agreement } \\
\text { ("Strongly agree" and "Agree") }\end{array}$ & $\begin{array}{c}\text { Practicality } \\
\text { ("A great deal" and "A lot") }\end{array}$ & $\begin{array}{c}\text { Applicability } \\
\text { ("Very easy" and "Easy") }\end{array}$ \\
\hline Age & $p=0.604$ & $p=0.808$ & $p=0.184$ \\
\hline Under 25 & $100.0 \%$ & $66.7 \%$ & $66.7 \%$ \\
\hline $25-34$ & $92.5 \%$ & $45.2 \%$ & $58.1 \%$ \\
\hline $35-44$ & $96.8 \%$ & $41.0 \%$ & $72.4 \%$ \\
\hline $45-54$ & $94.7 \%$ & $40.4 \%$ & $66.7 \%$ \\
\hline Over 55 & $100.0 \%$ & $47.6 \%$ & $71.4 \%$ \\
\hline Gender & $p=0.421$ & $p=0.737$ & $p=0.032^{*}$ \\
\hline Male & $95.1 \%$ & $72.2 \%$ & $63.4 \%$ \\
\hline Female & $96.2 \%$ & $68.8 \%$ & $73.5 \%$ \\
\hline Work experience (years) & $p=0.796$ & $p=0.268$ & $p=0.659$ \\
\hline $0-5$ & $67.9 \%$ & $75.2 \%$ & $95.4 \%$ \\
\hline $6-10$ & $66.3 \%$ & $66.3 \%$ & $95.7 \%$ \\
\hline $11-15$ & $67.4 \%$ & $73.9 \%$ & $93.5 \%$ \\
\hline$>15$ & $68.6 \%$ & $66.7 \%$ & $98.0 \%$ \\
\hline Professional role & $p=0.305$ & $p=0.704$ & $p=0.391$ \\
\hline Physician & $95.7 \%$ & $71.9 \%$ & $66.2 \%$ \\
\hline Nurses & $95.5 \%$ & $63.6 \%$ & $70.4 \%$ \\
\hline Institutional level & $p=0.512$ & $p=0.547$ & $p=0.194$ \\
\hline Primary care & $100 \%$ & $60.0 \%$ & $60.0 \%$ \\
\hline Secondary care & $93.6 \%$ & $76.6 \%$ & $77.7 \%$ \\
\hline Tertiary care & $95.6 \%$ & $70.3 \%$ & $75.5 \%$ \\
\hline Private practice status & $p=0.561$ & $p=0.015^{\star}$ & $p=0.680$ \\
\hline Private practice & $96.6 \%$ & $63.8 \%$ & $62.1 \%$ \\
\hline Governmental hospital & $95.2 \%$ & $72.5 \%$ & $68.3 \%$ \\
\hline $\begin{array}{l}\text { Number of COVID cases in the } \\
\text { hospital (cases/day) }\end{array}$ & $p=0.830$ & $p=0.214$ & $p=0.934$ \\
\hline 0 & $96.9 \%$ & $67.60 \%$ & $69.2 \%$ \\
\hline $1-10$ & $97.2 \%$ & $66.30 \%$ & $66.4 \%$ \\
\hline $11-20$ & $88.1 \%$ & $66.70 \%$ & $66.7 \%$ \\
\hline $21-30$ & $92.3 \%$ & $76.90 \%$ & $61.5 \%$ \\
\hline$>30$ & $96.7 \%$ & $78.90 \%$ & $68.9 \%$ \\
\hline Endoscopic volume on & $p=0.002^{*}$ & $p=0.120$ & $p=0.927$ \\
\hline COVID-19 cases (cases/month) & & & \\
\hline 0 & $83.3 \%$ & $100.0 \%$ & $100.0 \%$ \\
\hline $1-10$ & $67.5 \%$ & $95.8 \%$ & $51.5 \%$ \\
\hline $11-20$ & $76.6 \%$ & $92.2 \%$ & $57.8 \%$ \\
\hline $21-30$ & $80.0 \%$ & $100.0 \%$ & $50.0 \%$ \\
\hline$>30$ & $92.3 \%$ & $100.0 \%$ & $30.8 \%$ \\
\hline National COVID-19 prevalence & $p=0.178$ & $p=0.134$ & $p<0.001^{\star}$ \\
\hline Low prevalent & $96.7 \%$ & $75.0 \%$ & $77.5 \%$ \\
\hline High prevalent & $94.0 \%$ & $66.0 \%$ & $48.5 \%$ \\
\hline Trainee status & $p=0.891$ & $p=0.391$ & $p=0.737$ \\
\hline In-training & $93.3 \%$ & $70.0 \%$ & $77.8 \%$ \\
\hline Attending physician & $95.9 \%$ & $62.0 \%$ & $54.7 \%$ \\
\hline
\end{tabular}

COVID-19, coronavirus disease 2019

*Statistically significant. 
pists and nurses comes with experience. They also support the TAGE recommendation of assigning more experienced endoscopists to perform endoscopy for patients with COVID-19.

The lower sense of safety of the trainees, compared with their attending counterparts, is a critical observation that should be urgently addressed. Trainees, in spite of their limited experience, constitute a fundamental workforce in the hospital and may inevitably be allocated to the frontline amidst overwhelming medical demand. As opposed to attending physicians, trainees are more vulnerable to coercion and generally receive less training for mass-casualty events. ${ }^{26,27}$ Therefore, operational management should involve fellows in the development of emergency plans to strike a balance between high-quality patient care and the personal safety of trainees. ${ }^{28}$ It is also important to note that despite the high prevalence of COVID-19 in the countries of the respondents, only $26.3 \%$ had performed endoscopy in COVID-19 patients. This finding suggests that emergent endoscopy among these patients is not common.

The TAGE recommendation to postpone all elective cases has an inevitable economic impact on endoscopic practices. The significant disagreement on its practicality among re- spondents in private practice and governmental counterparts underscored the financial implications of these recommendations. Although there are no strict guidelines on when to resume general practice, the timing should be individualized according to the recommendations of local health authorities while exercising good clinical judgment.

In general, the TAGE recommendations are similar to those by other societies with only a few exceptions, as described in Table 4. Regarding scope reprocessing, although the TAGE recommendations were in agreement with those by the European Society of Gastrointestinal Endoscopy and the American Society of Gastrointestinal Endoscopy on virucidal efficacy of standard scope cleaning, TAGE experts were more concerned about accidental splashing or aerosolization during the pre-cleaning process while wiping, blowing air, flushing scope channels, or unplugging valves. As a result, an additional protocol aiming to protect reprocessing personnel was recommended; this was the use of alcohol wipes on the control knobs and the exterior of the endoscope with Peracetic acid immersion as the next step, considering its fast and broad virucidal and sporicidal activities. ${ }^{29}$ However, the adoption of this practice was controversial due to concerns about their

Table 4. Recommendations for Endoscopy during the COVID-19 Pandemic from International/National Societies of Gastroenterology/Gastrointestinal Endoscopy

\begin{tabular}{|c|c|c|c|c|c|c|}
\hline Society & Published & $\begin{array}{c}\text { Postpone } \\
\text { non urgent } \\
\text { procedures }\end{array}$ & Urgent procedures & $\begin{array}{l}\text { Pre-endoscopy } \\
\text { screening tool }\end{array}$ & Type of PPE recommended & $\begin{array}{c}\text { Scope cleaning } \\
\text { process }\end{array}$ \\
\hline $\begin{array}{l}\text { European Society } \\
\text { of Gastrointestinal } \\
\text { Endoscopy }\end{array}$ & $\begin{array}{l}18 \text { March } \\
2020\end{array}$ & yes & $\begin{array}{l}\text {-Acute GI bleeding and } \\
\text { anemia with hemody- } \\
\text { namic instability } \\
\text {-Foreign body } \\
\text {-Obstruction } \\
\text {-Acute cholangitis }\end{array}$ & Questionnaire & $\begin{array}{l}\text { Double gloves, mask } \\
\text { (FFP2/3), goggles or face } \\
\text { shield, waterproof gown, } \\
\text { hairnet, shoe covers }\end{array}$ & $\begin{array}{l}\text { Same as } \\
\text { pre-COVID-19 } \\
\text { era }\end{array}$ \\
\hline $\begin{array}{l}\text { World Endoscopy } \\
\text { Organization }\end{array}$ & $\begin{array}{l}24 \text { March } \\
2020\end{array}$ & yes & $\begin{array}{l}\text {-Upper GI bleeding, } \\
\text {-Foreign body } \\
\text {-Obstruction } \\
\text {-Acute cholangitis }\end{array}$ & Questionnaire & $\begin{array}{l}\text { Double gloves, mask (N95/ } \\
\text { FFP2/FF3/CAPR/ PAPR), } \\
\text { goggles or face shield, } \\
\text { waterproof gown, hairnet, } \\
\text { shoe covers }\end{array}$ & Not mentioned \\
\hline $\begin{array}{l}\text { American Society } \\
\text { for Gastrointestinal } \\
\text { Endoscopy }\end{array}$ & $\begin{array}{l}27 \text { March } \\
2020\end{array}$ & yes & $\begin{array}{l}\text {-Upper GI bleeding, } \\
\text {-Foreign body } \\
\text {-Obstruction } \\
\text {-Acute cholangitis } \\
\text {-Care of cancer }\end{array}$ & $\begin{array}{l}\text { Questionnaire } \\
\text { and body } \\
\text { temperature } \\
\text { measurement }\end{array}$ & $\begin{array}{l}\text { Gloves, mask (N95/FFP2), } \\
\text { goggles or face shield, } \\
\text { waterproof gown }\end{array}$ & $\begin{array}{l}\text { Same as } \\
\text { pre-COVID-19 } \\
\text { era }\end{array}$ \\
\hline $\begin{array}{l}\text { Thai Association } \\
\text { for Gastrointestinal } \\
\text { Endoscopy }\end{array}$ & $\begin{array}{l}25 \text { March } \\
2020\end{array}$ & yes & $\begin{array}{l}\text {-Acute GI bleeding } \\
\text {-Foreign body } \\
\text {-Obstruction } \\
\text {-Acute cholangitis } \\
\text {-Perforation and leakage } \\
\text {-Access for urgent feeding }\end{array}$ & $\begin{array}{l}\text { Questionnaire } \\
\text { and body } \\
\text { temperature } \\
\text { measurement }\end{array}$ & $\begin{array}{l}\text { Double gloves, mask (N95/ } \\
\text { FFP2/FF3/CAPR/ PAPR), } \\
\text { goggles or face shield, } \\
\text { waterproof gown, hairnet, } \\
\text { shoe covers }\end{array}$ & $\begin{array}{l}3 \text { additional } \\
\text { pre-cleaning } \\
\text { steps before } \\
\text { standard } \\
\text { reprocessing }\end{array}$ \\
\hline
\end{tabular}

COVID-19, coronavirus disease 2019; GI: gastrointestinal; PPE, personal protective equipment. 
proteinaceous fixative properties on the endoscope surface. ${ }^{30}$ Therefore, these additional agents should only be used for pre-cleaning steps before standard high-level disinfection.

This study benefited from a relatively large group of multinational respondents. By reaching out to those directly involved in endoscopy management during the COVID-19 pandemic and those who shared the published recommendations via social media platforms, the obtained responses were more likely to reflect the real-world adoption of the recommendations. Given that this was a large multinational survey, the differences in the demographic characteristics of the respondents were inevitable. Despite these differences, the respondents overwhelmingly agreed with nearly all aspects of the recommendations, suggesting that the perceptions of the importance of PPE, the case selection protocol, and the scope cleaning process adjustment during the COVID-19 pandemic were universal among healthcare personnel regardless of their geographical location, level of training, or available resources. However, the perceptions of the practicality and applicability of each recommendation differed with the local COVID-19 prevalence as the pivotal determining factor. Our findings emphasize that the guidelines of societies may not satisfy the "one size fits all" principle. They also demonstrate the crucial need for each endoscopy unit to adapt its practice pattern according to the local prevalence.

Our study was also subject to inherent limitations of a survey study that included recall and selection bias. Due to the international design of the study and the changing prevalence of COVID-19 in each country, the responses obtained may be subject to change over time. In addition, as further evidence on the aerosolization risk of endoscopy emerges, the official recommendations on optimal PPE and reprocessing methods for endoscopic procedures may be modified.

We conclude that using appropriate PPE and implementing optimal case selection for endoscopic practice during the COVID-19 pandemic remains a challenge, especially among less experienced endoscopists in highly prevalent countries, although the response of the respondents indicated a general agreement with the recommendations. TAGE recommendations, similar to other guidelines, should be taken only as general guidance, rather than as a compulsory standard. The personal sense of safety of endoscopy personnel is imperative in the management of an endoscopy unit during the pandemic. The optimal response to such an unprecedented public health crisis necessitates knowledge, preparedness, and multidisciplinary coordination to ensure proper resource availability and allocation.

Conflicts of Interest

Rungsun Rerknimitr is currently serving as an associate editor in Clinical
Endoscopy; however, he was not involved in the peer reviewer selection, evaluation, or decision process for this article. The authors have no potential conflicts of interest.

Funding

This research was also supported by the Center of Excellence for Innovation and Endoscopy in Gastrointestinal Oncology, Chulalongkorn University, Bangkok, Thailand.

Acknowledgment

The authors would like to thank the Thai Association of Gastrointestinal Endoscopy (TAGE) and the Endoscopy Nurse Society of Thailand (ENST) for the critical revision and support in distributing the questionnaire.

Author Contributions

Conceptualization: Rungsun Rerknimitr and Parit Mekaroonkamol

Data curation: PM, Kasenee Tiankanon, Fariha Shams, Ghias Un Nabi Tayyab, Julia Massaad, Saurabh Chawla, Stanley Khoo, Siriboon Attasaranya, Nonthalee Pausawasdi, Qiang Cai, Thawee Ratanachu-ek, Pradermchai Kongkham

Formal analysis: PM, KT, Rapat Pittayanon

Investigation: PM, KT, RP

Methodology: Rungsun Rerknimitr, PK, PM

Project administration: KT, PM

Resources: RR, PK

Supervision: $R R$

Validation: NP, TR, PK, RR

Writing-original draft: PM

Writing-review \& editing: KT, RP, Wiriyaporn Ridtitid, FS, GUNT, JM, SC, SK, SA, NP, QC, TR, PK, RR

ORCID

Parit Mekaroonkamol

Kasenee Tiankanon

Rapat Pittayanon

Wiriyaporn Ridtitid

Fariha Shams

Ghias Un Nabi Tayyab

Julia Massaad

Saurabh Chawla

Stanley Khoo

Siriboon Attasaranya

Nonthalee Pausawasdi

Qiang Cai

Thawee Ratanachu-ek

Pradermchai Kongkham

Rungsun Rerknimitr

https://orcid.org/0000-0002-3206-3431 https://orcid.org/0000-0001-8550-8142 https://orcid.org/0000-0001-6407-5245 https://orcid.org/0000-0002-6736-4402 https://orcid.org/0000-0001-9142-6629 https://orcid.org/0000-0003-3664-4644 https://orcid.org/0000-0002-7973-0027 https://orcid.org/0000-0001-6841-4929 https://orcid.org/0000-0002-1744-4674 https://orcid.org/0000-0001-7594-1428 https://orcid.org/0000-0002-3737-8555 https://orcid.org/0000-0002-9931-5410 https://orcid.org/0000-0002-8579-1547 https://orcid.org/0000-0001-5798-9217 https://orcid.org/0000-0001-6866-6886

\section{REFERENCES}

1. Bai Y, Yao L, Wei T, et al. Presumed Asymptomatic Carrier Transmission of COVID-19. JAMA 2020;323:1406-1407.

2. Li R, Pei S, Chen B, et al. Substantial undocumented infection facilitates the rapid dissemination of novel coronavirus (SARS-CoV-2). Science 2020;368:489-493.

3. Gu J, Han B, Wang J. COVID-19: Gastrointestinal manifestations and potential fecal-oral transmission. Gastroenterology 2020;158:1518-1519.

4. Song Y, Liu P, Shi XL, et al. SARS-CoV-2 induced diarrhoea as onset symptom in patient with COVID-19. Gut 2020;69:1143-1144.

5. Xiao F, Tang M, Zheng X, Liu Y, Li X, Shan H. Evidence for gastrointes- 
tinal infection of SARS-CoV-2. Gastroenterology 2020;158:1831-1833. e3.

6. van Doremalen N, Bushmaker T, Morris DH, et al. Aerosol and surface stability of SARS-CoV-2 as compared with SARS-CoV-1. N Engl J Med 2020;382:1564-1567.

7. Chiu PWY, Ng SC, Inoue H, et al. Practice of endoscopy during COVID-19 pandemic: position statements of the Asian Pacific Society for Digestive Endoscopy (APSDE-COVID statements). Gut 2020;69:991-996.

8. Soetikno R, Teoh AYB, Kaltenbach T, et al. Considerations in performing endoscopy during the COVID-19 pandemic. Gastrointest Endosc 2020;92:176-183.

9. Chapman S. Hot air? BMJ 2001;323:1449.

10. Johnston ER, Habib-Bein N, Dueker JM, et al. Risk of bacterial exposure to the endoscopist's face during endoscopy. Gastrointest Endosc 2019;89:818-824.

11. Tran K, Cimon K, Severn M, Pessoa-Silva CL, Conly J. Aerosol generating procedures and risk of transmission of acute respiratory infections to healthcare workers: a systematic review. PLoS One 2012;7:e35797.

12. American Society for Gastrointestinal Endoscopy. JOINT GI SOCIETY MESSAGE: COVID-19 clinical insights for our community of gastroenterologists and gastroenterology care providers [Internet]. Downers Grove (IL): ASGE; c2020 [cited Apr 21, 2021]. Available from: https:// www.asge.org/home/joint-gi-society-message-covid-19.

13. Kongkam P, Tiankanon K, Ratanalert S, et al. The practice of endoscopy during the COVID-19 pandemic: recommendations from the Thai association for gastrointestinal endoscopy (TAGE) in collaboration with the endoscopy nurse society (Thailand). Siriraj Medical Journal 2020;72.

14. Philip M, Lakhtakia S, Aggarwal R, Madan K, Saraswat V, Makharia G. Joint guidance from SGEI, ISG and INASL for gastroenterologists and gastrointestinal endoscopists on the prevention, care, and management of patients with COVID-19. J Clin Exp Hepatol 2020;10:266-270.

15. Repici A, Maselli R, Colombo M, et al. Coronavirus (COVID-19) outbreak: what the department of endoscopy should know. Gastrointest Endosc 2020;92:192-197.

16. Pryor A. SAGES and EAES Recommendations Regarding Surgical Response to COVID-19 Crisis [Internet]. Los Angeles (CA): SAGES; c2020 [cited 2021 Apr 21]. Available from: https://www.sages.org/recommendations-surgical-response-covid-19/.

17. Rerknimitr R, Soetikno R, Ratanachu-Ek T, Tiankanon K, Kongkam P, Ridtitid W. Additional measures for bedside endoscope cleaning to prevent contaminated splash during COVID-19 pandemic. Endoscopy 2020;52:706-707.

18. WHO Coronavirus (COVID-19) Dashboard [Internet]. Geneva: WHO; c2020 [cited 2021 June 2]. Available from: https://covid19.who.int/.

19. Barlett JE, Kotrlik J, Higgins C. Organizational research: determining appropriate sample size in survey research. Information Technology, Learning, and Performance Journal 2001;19:43-50.

20. World Health Organization. Rational use of personal protective equipment for coronavirus disease (COVID-19) and considerations during severe shortages: interim guidance, 6 April 2020 [Internet]. Geneva: WHO; c2020 [cited 2021 Apr 21]. Available from: https://apps.who.int/ iris/handle/10665/331695.

21. National Center for Immunization and Respiratory Diseases. Centers for disease control and prevention [Internet]. Atlanta (GA): CDC; c2020 [updated 2020 Jul 16; cited 2021 Apr 21]. Available frrom: https://www. cdc.gov/coronavirus/2019-ncov/hcp/ppe-strategy/index.html.

22. BBC. Coronavirus: Medics to be asked to reuse gowns amid shortage fears. [Internet]. London: BBC NEWS; c2020 [updated 2020 Apr 17; cited 2021 Apr 21]. Available from: https://www.bbc.com/news/uk52333157.

23. CNN. Doctors and nurses alarmed about lack of supplies [Internet]. Atlanta (GA): CNN; c2020 [updated 2020 Mar 27; cited Apr 21 2021]. Available from: https:/edition.cnn.com/videos/health/2020/03/27/medical-workers-shortage-of-protective-equipment-griffin-dnt-vpx.cnn.

24. CNN. Faced with shortages, hospitals and companies work to extend use of N95 masks [Internet]. Atlanta (GA): CNN; c2020 [updated Apr 10; cited Apr 21 2021]. Available from: https://edition.cnn.com/2020/04/10/ politics/n95-masks-coronavirus-pandemic/index.html.

25. Liu K, Chen Y, Lin R, Han K. Clinical features of COVID-19 in elderly patients: a comparison with young and middle-aged patients. J Infect 2020;80:e14-e8.

26. Martin SD, Bush AC, Lynch JA. A national survey of terrorism preparedness training among pediatric, family practice, and emergency medicine programs. Pediatrics 2006;118:e620-e626.

27. Niska RW, Burt CW. Bioterrorism and mass casualty preparedness in hospitals: United States, 2003. Adv Data 2005;1-14.

28. World Health Organization. COVID-19: operational guidance for maintaining essential health services during an outbreak: interim guidance, 25 March 2020. Geneva: WHO; c2020 [cited 2021 Apr 21]; Available at: https://apps.who.int/iris/handle/10665/331561.

29. Becker B, Brill FHH, Todt D, et al. Virucidal efficacy of peracetic acid for instrument disinfection. Antimicrob Resist Infect Control 2017;6:114.

30. Costa D de M, Lopes LK de O, Hu H, Tipple AFV, Vickery K. Alcohol fixation of bacteria to surgical instruments increases cleaning difficulty and may contribute to sterilization inefficacy. Am J Infect Control 2017;45:e81-e86. 